\title{
触 New Disease Reports \\ First report of cassava brown streak disease and associated Ugandan cassava brown streak virus in Burundi
}

\author{
S. Bigirimana ${ }^{1}$, P. Barumbanze ${ }^{1}$, P. Ndayihanzamaso ${ }^{1}$, R. Shirima ${ }^{2}$ and J.P. Legg $^{2}$ \\ ${ }^{1}$ Institut des Sciences Agronomiques du Burundi, Gitega, Burundi; ${ }^{2}$ International Institute of Tropical Agriculture, Dar es \\ Salaam, Tanzania
}

*E-mail: simbig2002@yahoo.fr

Received: 07 Oct 2011. Published: 15 Dec 2011. Keywords: CBSD, Bemisia tabaci

Cassava brown streak disease (CBSD) is a virus disease of great economic importance in East and Central Africa. The earliest reports recognised CBSD as a virus disease spread both through infected cuttings and by a whitefly vector (Storey, 1936). New outbreaks in higher altitude areas of East Africa were reported in the mid-2000s (Alicai et al., 2007). CBSD is caused by two virus species: Cassava brown streak virus (CBSV) and Ugandan cassava brown streak virus (UCBSV) (Potyviridae: Ipomovirus) (Mbanzibwa et al., 2011). Neither species of the cassava brown streak viruses (CBSVs) has previously been reported from Burundi. In June 2011, visits to cassava fields in parts of Burundi bordering Lake Tanganyika revealed the widespread occurrence of CBSD-like symptoms. To test for the presence of CBSVs, a survey was conducted from June 21-26, covering 29 sites in Cibitoke, Bubanza, Bujumbura Rural, Bururi, Makamba, Gitega and Rutana Provinces. Incidence of plants symptomatic for CBSD was determined by assessing 30 plants at each site. Samples were collected from both symptomatic and symptomless plants. CBSD foliar symptoms (Fig. 1) were observed at 15 sites with an average incidence of $15.3 \%$. Incidence was less in local varieties (1.1\%, two out of seven sites) than in improved varieties $(19.6 \%, 13$ out of 22 sites). The average foliar symptom severity of 2.3 was low ( $2=$ mildest; $5=$ most severe). Tuberous root symptoms characteristic of CBSD were observed at several sampled sites (Fig. 2). The mean adult Bemisia tabaci whitefly abundance of $>38$ per top five leaves was high, in common with other CBSD outbreak areas of the Great Lakes region (Legg et al., 2011).

A total of 121 cassava leaf samples were analysed with standard RT-PCR at ISABU, Burundi, and using real-time RT-PCR at IITA-Tanzania. Total RNA was isolated from samples using a modified CTAB method. Two primer sets were used for the standard RT-PCR: CBSV-UG/1F (5'-CGTTTGTGATAAAAGCTGCTA-3') with CBSV-UG/2R (5'-TGCAAACAGTCTTGTYTTTG-3') and CBSV-F3 (5'-GARCCRATGTAYAAATTTGC -3') with CBSV-R3 (5'-AGGAGCWGCTARWGCAAA -3') (Abarshi et al., 2011). Real-time RT-PCR employed coat protein specific TaqMan probes which amplified either CBSV or UCBSV (FERA, 2010). Standard RT-PCR produced amplicons of expected sizes for 54 of 59 symptomatic samples and four of 62 symptomless samples. Real-time RT-PCR gave positive $\mathrm{Ct}$ values for an additional two symptomatic and 11 symptomless samples. Ct values were obtained exclusively with the UCBSV probe. RT-PCR products ( $280 \mathrm{nt})$ from the F3/R3 primer pair were bi-directionally sequenced and contigs assembled. Ten sequences produced in this way were deposited in GenBank with accession numbers, JN817411-JN817420. BLASTn analysis revealed that the Burundi isolates were most closely related (96-100\%) with UCBSV sequences from Uganda (HM346952; HM171315) and Malawi (HM171303).

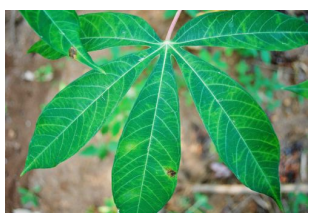

Figure 1 disease and associated Ugandan cassava brown streak virus in Burundi. New Disease Reports 24, 26.

[doi:10.5197/j.2044-0588.2011.024.026]

(c) 2011 The Authors

This report was published on-line at www.ndrs.org.uk where high quality versions of the figures can be found.

These data provide the first confirmation that CBSD is present in Burundi, and show that UCBSV is so far the only virus species found in association with the disease in the six provinces of western and southern Burundi surveyed. The results highlight the need for urgent measures to mitigate the outbreak.

\section{Acknowledgements}

Funded through GLCI, a project co-ordinated by Catholic Relief Services and funded by the Bill and Melinda Gates Foundation.

\section{References}

Abarshi MM, Mohammed IU, Jeremiah SC, Legg JP, Kumar L, Hillocks RJ, Maruthi MN, 2011. Multiplex RT-PCR assays for the simultaneous detection of both RNA and DNA viruses infecting cassava and the common occurrence of mixed infections by two cassava brown streak viruses in East Africa. Journal of Virological Methods. In press. [doi:10.1016/j.jviromet.2011.10.020]

Alicai T, Omongo CA, Maruthi MN, Hillocks RJ, Baguma Y, Kawuki R, Bua A, Otim-Nape GW, Colvin J, 2007. Re-emergence of cassava brown streak disease in Uganda. Plant Disease 91, 24-29.

[doi:10.1094/PD-91-0024]

FERA, 2010. FERA Appendix 3b - KEPHIS Training Manual - PCR 2. GCLI Document Library. Great Lakes Cassava Initiative. [http://iglci.crs.o $\mathrm{rg} /$ DocumentLibrary/Documents/Forms/AllItems.aspx?RootFolder=\%2fD ocumentLibrary $\% 2$ fDocuments $\% 2$ fYear\%203\%20annual\%20report-\%20d isease\%20appendices\&FolderCTID $=\&$ View $=\{C$ C3165B0-DCE5-4271-86 7C-AF43E7D09B76\}]

Legg JP,Jeremiah SC,Obiero HM, Maruthi MN, Ndyetabula I,

Okao-Okuja G, Bouwmeester H, Bigirimana S, Tata-Hangy W, Gashaka G, Mkamilo G, Alicai T, Lava Kumar P, 2011. Comparing the regional epidemiology of the cassava mosaic and cassava brown streak pandemics in Africa. Virus Research 159, 161-170.

[doi:10.1016/j.virusres.2011.04.018]

Mbanzibwa DR, Tian YP, Tugume AK, Patil BL, Yadav JS, Bagewadi B, Abarshi, MM, Alicai T, Changadeya W, Mkumbira J, Muli MB, Mukasa SB, Tairo F, Baguma Y, Kyamanywa S, Kullaya A, Maruthi MN, Fauquet CM, Valkonen JPT, 2011. Evolution of cassava brown streak disease-associated viruses. Journal of General Virology92, 974-987. [doi:10.1099/vir.0.026922-0]

Storey HH, 1936. Virus diseases of East African plants. VI-A progress report on studies of the disease of cassava. East African Agricultural Journal 2, 34-39.

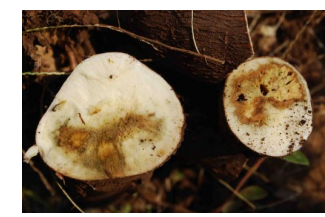

New Disease Reports is a peer-reviewed on-line journal published by the British Society for Plant Pathology, for more information visit http://www.ndrs.org.uk/ 